\title{
Roles of Telomere Biology in Cell Senescence, Replicative and Chronological Ageing
}

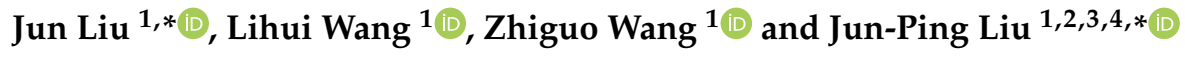 \\ 1 Institute of Ageing Research, School of Medicine, Hangzhou Normal University, Hangzhou 311121, \\ Zhejiang, China; wanglihui@hznu.edu.cn (L.W.); zhgwang@hznu.edu.cn (Z.W.) \\ 2 Department of Immunology, Monash University Faculty of Medicine, Melbourne, Vitoria 3004, Australia \\ 3 Hudson Institute of Medical Research, Clayton, Victoria 3168, Australia \\ 4 Department of Molecular and Translational Science, Monash University, Clayton, Victoria 3168, Australia \\ * Correspondence: junliu262@hznu.edu.cn (J.L.); jun-ping.liu@monash.edu (J.-P.L.); Tel.: +86-0571-28861733 \\ (J.L.); Tel.: +86-0571-28861708 (J.-P.L.)
}

Received: 22 November 2018; Accepted: 9 January 2019; Published: 15 January 2019

\begin{abstract}
Telomeres with G-rich repetitive DNA and particular proteins as special heterochromatin structures at the termini of eukaryotic chromosomes are tightly maintained to safeguard genetic integrity and functionality. Telomerase as a specialized reverse transcriptase uses its intrinsic RNA template to lengthen telomeric G-rich strand in yeast and human cells. Cells sense telomere length shortening and respond with cell cycle arrest at a certain size of telomeres referring to the "Hayflick limit." In addition to regulating the cell replicative senescence, telomere biology plays a fundamental role in regulating the chronological post-mitotic cell ageing. In this review, we summarize the current understandings of telomere regulation of cell replicative and chronological ageing in the pioneer model system Saccharomyces cerevisiae and provide an overview on telomere regulation of animal lifespans. We focus on the mechanisms of survivals by telomere elongation, DNA damage response and environmental factors in the absence of telomerase maintenance of telomeres in the yeast and mammals.
\end{abstract}

Keywords: telomere; ageing; lifespan; senescence; replicative ageing; chronological ageing; yeast

\section{Telomere Structure and Maintenance}

Telomere contains telomeric DNA and its binding proteins. The telomeric DNA sequence is $\mathrm{TG}_{1-3}$, terminated with a $3^{\prime}$ end G-rich overhang, synthesized by telomerase that consists of the catalytic subunit Est2 [1], the RNA template Tlc1 [2], two regulatory subunits-Est1 [3] and Est3 [4], the Yku80 subunit [5] and the telomeric single-stranded DNA binding protein-Cdc13 [6], Pop1, Pop6 and Pop7 [7] in the budding yeast. In addition, the telomere binding protein complex "shelterin-like telosome" consists of telomeric duplex-region binding protein Rap1 that recruits Rif1, Rif2, Sir3 and Sir4 to telomeres via the carboxyl domains to form Rap1-Rif1/2 and Rap1-Sir3/4 capping complexes at telomeres. Cdc13 is also an integral component of the CST (Cdc13-Stn1-Ten1) complex that is conserved from yeast to human for single-strand telomere capping and regulation of the C-strand telomeres $[8,9]$. Telomeres cannot be fully replicated by DNA polymerases due to the "end replication" problem [10-12]. Most eukaryotes evolve to maintain their telomeres with specific machineries including the reverse transcriptase telomerase that employs an intrinsic RNA template to reverse transcribe the G-rich nucleotide sequence to the $3^{\prime}$ ends of the G-rich strand of telomeres. Several reviews have published elsewhere on yeast telomere biology $[13,14]$ and telomere length regulation [15].

In human and mouse cells, telomere DNA sequence contains (TTAGGG) $n$ repeats and telomerase consists of the catalytic subunit TERT, RNA component TERC, dyskerin (DKC), nucleolar protein 10 
(NOP10), non-histone protein 2 (NHP2), GAR1 (encoding H/ACA ribonucleoprotein complex subunit 1) and telomerase Cajal body protein 1 (TCAB1). The shelterin complex contains the duplex-region binding proteins telomeric repeat binding factor 1 (TRF1) and TRF2 that recruit other four components: protection of telomeres 1 (POT1), repressor/activator protein 1 (RAP1), TRF1-interacting nuclear factor 2 (TIN2) and TPP1 (adrenocortical dysplasia protein homologue, ACD). These subunits form a complex called shelterin to coat and cap telomeric DNA [16,17], deficiency any of which may cause telomere dysfunction and cell senescence as for the case of POT1 that is a single-stranded telomeric DNA binding protein involved in ATR-dependent DNA damage response [18]. TRF2 and TPP1/POT1 inhibit two distinct telomere-threatening $5^{\prime}$ end-resection pathways that are differentially regulated by the ATM (yeast Tel1 orthologue) and ATR (yeast Mec1 orthologue) DNA damage signaling kinases [19]. One pathway is ATM-activated CtIP/MRN (Mre11-Rad50-Nbs1)-mediated limited resection, which is inhibited by TRF2; the other is ATR-stimulated Exo1/BLM-mediated extensive resection which is inhibited by TPP1/POT1 [19]. Both 5' end-resection pathways are repressed by 53BP1 and hRif1, which are all stimulated by ATM and ATR kinases that are suppressed by shelterin complex [19].

\section{Cell Replicative Ageing versus Cell Replicative Senescence}

Ageing is defined as age-dependent functional decline with gradual losses of reproductivity, which is determined by multiple genetic and environmental factors. Replicative ageing represents reproductive ageing in budding yeast, referring to the time-dependent decline of the capacity of a mother cell to produce its daughter cells [20]. A mystery if a cell divides unendingly to produce its daughter cells was unveiled in 1959. Mortimer and Johnston reported for the first time that single baker's yeast cell produces only a fixed number of daughter cells by asymmetrical budding before the mother cells enter a senescent state and lyse, with the limited budding potential named replicative (reproductive) lifespan [20]. This study demonstrated that instead of chronological time passage, cell budding results in replicative ageing in the single-cell eukaryotic organism.

Since telomerase is expressed in wild-type yeast cells, replicative ageing appears not to be set off by critically short telomeres, potentially allowing quantitative analysis of cell replicative lifespan in the yeast Saccharomyces cerevisiae model system to identify genes and chemical compounds in the regulation of cell replicative ageing [21-26]. On the other hand, the concept of cell replicative senescence (or cell senescence hereafter) refers to the state of permanent cell cycle arrest caused by consecutive symmetrical cell duplications, critically short telomeres and DNA damage response in yeasts and mammals [3,27]. However, cells with critically short telomeres are able to evade senescence by lengthening their telomeres via amplification of the subtelomeric $Y^{\prime}$ elements [28] and homologous recombination between the telomere-end heterogeneous $\mathrm{TG}_{1-3}$ sequences [29].

In human somatic diploid cells, Leonard Hayflick and his colleagues reported in early 1960s that cultured fibroblasts become aged with limited cell divisions [30,31]. This is because human normal somatic diploid cells do not have significant telomerase activity and fail to maintain their short telomeres so that cells enter a permanent cell cycle arrest. The notion of "Hayflick limit" denotes that somatic cells divide a fixed number of times, with human cells such as fibroblasts dividing forty to sixty times, before cell senescence [30-32].

In the budding yeast Saccharomyces cerevisiae, measuring cell senescence was invaluable to identify the genes that are essential for telomerase recruitment and assembly [1,3,4]. Two types of yeast survivors evaded from senescence with critically short telomeres have been discovered $[28,29]$ (see below). However, there has been relatively scarce evidence yet to demonstrate molecular interactions between the pathways that lead to cell replicative senescence (caused by critically short telomeres) and replicative (reproductive) ageing independent of telomere length.

\section{Cell Chronological Ageing}

A chronological ageing model was reported first by Longo and colleagues in the model system Saccharomyces cerevisiae, showing that non-dividing yeast cells lose their viabilities in a manner 
depending on both nutrient sufficiency and age, in order to model post-mitotic ageing of human cells such as neurons and muscle cells $[33,34]$. Chronological lifespan is usually defined as the time period when cells remain viable at stationary phase $\left(G_{0}\right.$ phase) [33]. The budding yeast post-mitotic cell ageing usually undergoes for 1-2 months of survival and has been widely used in ageing research [26,35-42]. It is believed that evolutionarily conserved key molecules in the polarization processes from yeast budding and mating to metazoan neuronal outgrowth and spinogenesis are homologous, potentially making the yeast chronological ageing process as a useful model for the non-dividing human cell ageing research [43-49].

\section{Roles of Telomere Length in Cell Senescence, Replicative and Chronological Ageing}

It has become evident that critically short telomeres in the absence of telomerase cause cell senescence, while reintroduction of telomerase rescues senescence [3,50], indicating a causal relationship between critically short telomeres and cell senescence [51]. The first telomerase gene identified was in yeast, named EST1 (ever shorter telomeres) [3]. Cells with EST1 gene knock-out are not immediately unviable but rather senesce following successive passages with telomeres gradually shortened to critically short length [3]. These studies show that when telomeres are critically short, cell senescence mechanisms are activated to drive cells into a permanent cell cycle arrest. Reintroduction of telomerase to the cells null of telomerase increases the replicative lifespan, indicating a pivotal role of telomere length above the critically short point in cell replicative lifespan [50,52-54].

However, it has been shown that inappropriately prolonged telomeres shorten budding yeast replicative lifespan, whereas significantly shorter-than-normal telomere length due to telomerase deficiency extends yeast replicative lifespan [55]. Consistently, preventing telomere lengthening by inhibiting telomere recombination promotes yeast replicative lifespan extension [56]. Why is the lifespan extended in the strain with shorter telomeres? Mechanistic studies show that the yeast chromatin silencing machinery, encoded by SIR2, SIR3 and SIR4, undergoes redistribution from telomeres to non-telomere sites when telomeres are shortened to increase heterochromatin maintenance, genome stability and the lifespan, and deletion of either SIR3 or SIR4 decreases the lifespan [55]. More recently, no effect of long telomeres on vegetative cell division, meiosis or in cell chronological lifespan is observed in the yeast [57]. During chronological ageing, longer telomeres remain stable albeit without affecting chronological lifespan [42]. These strains with 2-4 folds longer telomeres do not carry any plasmids or gene deletions, potentially applicable to assess the relationship between overlong telomeres and chronological lifespan [42]. It thus appears that neither replicative nor chronological lifespan benefits from longer-than-normal telomeres.

\section{Role of Telomere Shortening in Multicellular Organismal Ageing}

Ageing of multicellular organisms is more complex than single eukaryotic cell organism. Telomere lengthening by activating telomerase increases longevity in mice with [58] or without risking tumorigenesis $[59,60]$ and extends replicative lifespan in human cells $[50,53,54]$. Telomeres longer than normal are associated with diminished age-related pathology in humans [61]. In the nematode Caenorhabditis elegans, long telomeres associated with overexpression of $h n R N P-1$ (encoding heterogeneous nuclear ribonucleoprotein A1) are correlated with lengthened organismal lifespan [62]. On the other hand, telomeres longer than normal are associated with increased risks of vascular hypertension $[63,64]$ and lung adenocarcinoma $[58,65]$.

Interestingly, it is not only telomere DNA damage response but also glucose homeostasis and inflammation that mediate the lifespan changes inflicted by altered telomere lengths in mammals. Telomerase catalytic subunit TERT binds cell membrane glucose transporter to enhance glucose import; inhibition of TERT halves glucose intake but overexpressing TERT triples the uptake [66] and glucose-enriched substitution feeding extends the short lifespan by $20 \%$ of the mice deficient of telomerase RNA subunit [67]. These are consistent with the notion that glucose homeostasis and energy sufficiency are fundamental in lifespan regulation in the maintenance of short lifespan associated with 
telomerase deficiency and telomere dysfunction. It is noteworthy that increased glycolysis extends fish lifespan by inhibiting polycomb repressive complexes (PRCs)-mediated H3K27me3 or expressing genes for glycolysis [68].

Recently, we showed that senescence-associated low grade inflammation (SALI) is involved in the settings of telomere dysfunction and shortening in ageing [69]. Deficiency of either TERT or TERC results in telomere dysfunction and shortening, SALI, losses of tissue stem cells and short lifespan in mice [69]. The chronic sterile SALI appears to cause telomere dysfunction in various tissues of spleen, colon and liver in addition pulmonary epithelia in mice [69]. In addition to a causal role of telomeric DNA injury to inflammation, as parts of the vicious cycle between inflammation and telomeric DNA injury, inflammatory cytokine TGF- $\beta$ inhibits telomerase gene expression $[70,71]$. Moreover, telomere shortening induces interferon- $\beta$ (IFN- $\beta$ ) signaling and the increased IFN- $\beta$ is required in premature ageing and death induced by TERC deficiency with the mechanism downstream of telomeric DNA damage response [72]. Furthermore, inhibition of IFN- $\beta$ dramatically rescuing the short lifespan imposed upon by telomerase deficiency [72].

During telomeric DNA damage response, both p16 and p21 play critical role in arresting the cell cycle temporarily for DNA damage repairs or permanently to render cell replicative senescence if damages are irreparable. More interestingly, studies demonstrate that $\mathrm{p} 16$ and $\mathrm{p} 21$ play distinct roles in regulating the lifespan of mice carrying telomeric DNA damages, with predominantly single-stranded ATR-dependent telomere DNA damage induced by deficiency of POT1 component of shelterin [18]. Deficiency of p16 drastically shortens the lifespans of mice with deficiency of POT1 or both POT1 and telomerase RNA subunit, suggesting that p16 is required for survival with telomeric DNA dysfunction [18]. In a stark contrast, however, p21 deficit remarkably extends the lifespan of mice with POT1 deficiency, without triggering ATR-dependent DNA damage response and genome instability, suggesting that p21 is required for DNA damages and short lifespan in telomere dysfunction [18].

In the mice, although telomere shortens $\sim 100$ times faster than that in humans, it is the rate of increase in the percentage of short telomeres, rather than the rate of telomere shortening per month, that matters in predicting lifespan [73]. The maximal lifespan of different mammals differs significantly by more than 100 folds, ranging from about 2 years in shrews to $>200$ years in bowhead whales [74]. Telomeres shorten as a function of ages in old animals, including humans with shorter telomeres in elder people ( $>60$ years) being a prognosis for higher mortality [75]. In the long lived birds and mammals, telomeres shorten more slowly [76]. In the longevity naked and the blind mole rats that are two subterranean rodent species, telomerase is activated in somatic tissues that lack replicative senescence and resist tumorigenesis $[77,78]$. These studies confirm that telomere maintenance contributes to the regulation of lifespan and longevity significantly.

\section{Telomere Maintenance by Recombination, Genome Instability and Cell Replicative and Chronological Ageing}

In the yeast Saccharomyces cerevisiae, cells deficient of telomerase evade cellular senescence triggered with critically short telomeres to survive by either amplification of subtelomeric $Y^{\prime}$ elements (type I survivor) [28] or telomere-end $\mathrm{TG}_{1-3}$ sequence recombination through homologous recombination (type II survivor) [29] (Figure 1). However, the telomerase-null post-senescent type II survivors with enhanced telomere recombination exhibit accelerated cellular replicative ageing [52]. In the absence of telomerase activity for a short term (about 25-30 generations post telomerase inactivation), the cells experience a detectable genomic instability [79]. In response to transient DNA replication stress, altered cell-cycle dynamics occurs even in young mother cells with accelerated replicative ageing independent of telomere length [79]. This premature onset of cell senescence induced by telomerase deficiency and subsequent accelerated replicative ageing induced by telomere homologous recombination may reflect telomere uncapping events in the mother cells, which requires further investigation.

The mechanisms by which the subtelomeric $Y^{\prime}$ elements get amplified to underpin the type I survivors remain largely elusive. Whether or not specific telomeric proteins play a role in coordinately 
regulated telomere homeostasis requires investigation. Sir2, Sir3 and Sir4 along with Rif1 and Rif2 are localized to duplex telomeres by binding to the C-termini of Rap1 [13,14]. Whereas Rif1 and Rif2 are negative regulators of telomerase recruitment to telomeres [80], Sir4 recruits Sir2 and Sir3 to participate in chromatin silencing [81] by interacting with not only Rap1 but also Yku80 [82,83]. While binding of Yku80/70 to telomerase TLC1 and telomeric DNA is mutually exclusive to each other [84], Sir4 is required to mediate the Yku80-TLC1 recruitment to telomeres $[85,86]$. Thus, it is tempting to hypothesize that in the absence of telomerase recruitment, Sir2, Sir3 and Sir4 along with Rif1 and Rif2 are involved in regulating the type II survivor lifespan.

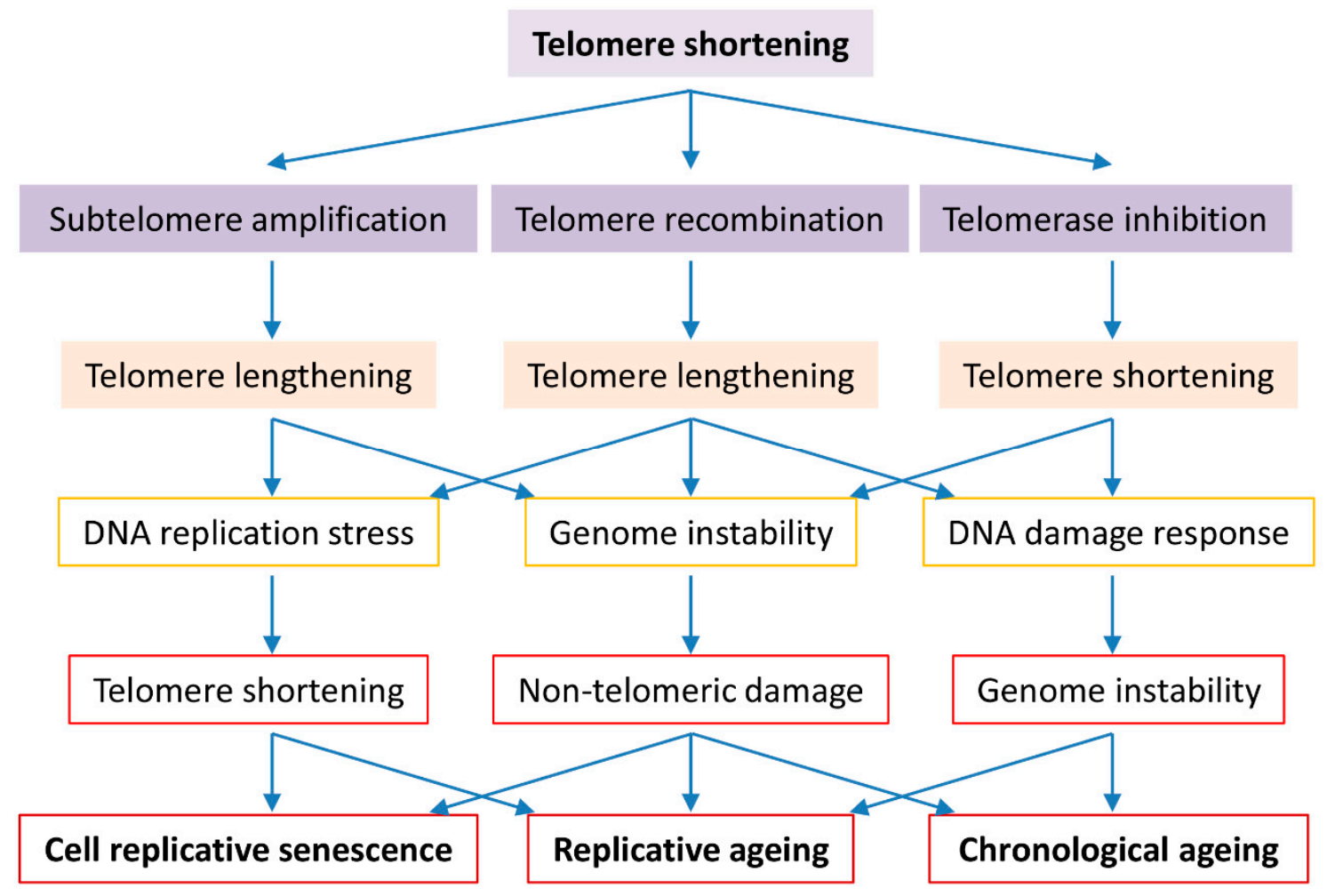

Figure 1. Roles of telomere biology in cell senescence, replicative and chronological ageing. Cells evolve to have regulated telomerase activity to preserve telomere homeostasis which is vital to genome stability in organism ageing. Short telomeres are maintained by telomerase in the early stage, telomere DNA homologous recombination or subtelomeric DNA amplification in the late stage of telomere shortening. Telomerase inactivation results in critically short telomeres that either activate the cell cycle check-point resulting in cell senescence or promote telomere-telomere recombination or subtelomere amplification resulting in genome instability and replicative difficulty. Long telomere associated genome instability and replicative difficulty cause not only telomere shortening but also non-telomeric damages, culminating in cell senescence, replicative ageing and accelerated chronological ageing.

Constitutive telomerase activity is observed by experimentally tethering the telomerase catalytic subunit Est2 to the single-stranded DNA binding protein Cdc13 with ectopic expression of the fusion gene CDC13-EST2 [42,87]. However, the constitutively increased telomerase activity results in shortened chronological lifespan [42]. CDC13-EST2 ectopic expression culminates in 2-4 folds longer telomeres but with significant genome instability including accumulated extra chromosomal rDNA circle species (ERC), frequent CAN1 marker gene mutations and gross chromosomal rearrangement (GCR) in an age-dependent manner [42]. Moreover, the significantly increased genome instability issuppressed by down-regulation of the evolutionarily conserved TORC1 (the target of rapamycin complex 1)-Sch9 pathway [42], suggesting that pharmaceutical strategies (e.g., rapamycin and caffeine [88]) are 
potentially applicable to stabilize the genome instability caused by constitutive active telomerase to increase lifespan.

\section{Perspectives}

Telomeres are lengthened by mechanisms including telomerase-mediated reverse transcription, subtelomeric DNA amplification and telomeric DNA homologous recombination. Uncontrolled telomere lengthening such as end-to-end joining is by and large at the expenses of risking premature ageing and related disorder such as cancer. Moreover, the mechanisms that determine the different aspects of longevity, premature replicative senescence and chronological ageing appear to hinge on the extensity and intensity of telomeric DNA abnormality and on the fidelity of DNA damage response and repair. Investigations of effective and sufficient regulation of telomeric DNA damage response and repair, by examining the molecular interplays between the different pathways of telomere maintenance for example, will shed light on the mechanisms of preventing telomere damages by environmental stresses (e.g., ultraviolet radiation and oxidative stress) in ageing. Thus, elucidation of the molecular functions, the structures conferring the specific functions of telomere proteins and how environmental stress impacts on the proteostasis of telomere proteins will inform on the means to intercept stress-induced organismal premature ageing for longevity.

Funding: This work was supported by the National Natural Science Foundation of China (31501110 to J.L., 81530039 to J.P.L.), the Start-up Research Program of Hangzhou Normal University (2018QDL010 to J.L.), China Postdoctoral Science Foundation (2014M551470 to J.L.) and Postdoctoral Research Program of Shanghai Institutes for Biological Sciences, Chinese Academy of Sciences (2014KIP305 to J.L.).

Conflicts of Interest: The authors declare no conflict of interest.

\section{References}

1. Lendvay, T.S.; Morris, D.K.; Sah, J.; Balasubramanian, B.; Lundblad, V. Senescence Mutants of Saccharomyces cerevisiae With a Defect in Telomere Replication Identify Three Additional EST Genes. Genetics 1996, 144, 1399-1412. [PubMed]

2. Singer, M.S.; Gottschling, D.E. TLC1: Template RNA component of Saccharomyces cerevisiae telomerase. Science 1994, 266, 404-409. [CrossRef] [PubMed]

3. Lundblad, V.; Szostak, J.W. A mutant with a defect in telomere elongation leads to senescence in yeast. Cell 1989, 57, 633-643. [CrossRef]

4. Hughes, T.R.; Evans, S.K.; Weilbaecher, R.G.; Lundblad, V. The Est3 protein is a subunit of yeast telomerase. Curr. Biol. 2000, 10, 809-812. [CrossRef]

5. Gravel, S.; Larrivee, M.; Labrecque, P.; Wellinger, R.J. Yeast Ku as a Regulator of Chromosomal DNA End Structure. Science 1998, 280, 741-744. [CrossRef] [PubMed]

6. Nugent, C.I.; Hughes, T.R.; Lue, N.F.; Lundblad, V. Cdc13p: A Single-Strand Telomeric DNA-Binding Protein with a Dual Role in Yeast Telomere Maintenance. Science 1996, 274, 249-252. [CrossRef] [PubMed]

7. Lemieux, B.; Laterreur, N.; Perederina, A.; Noel, J.-F.; Dubois, M.-L.; Krasilnikov, A.S.; Wellinger, R.J. Active Yeast Telomerase Shares Subunits with Ribonucleoproteins RNase P and RNase MRP. Cell 2016, 165, 1171-1181. [CrossRef] [PubMed]

8. Giraud-Panis, M.J.; Teixeira, M.T.; Geli, V.; Gilson, E. CST meets shelterin to keep telomeres in check. Mol. Cell 2010, 39, 665-676. [CrossRef] [PubMed]

9. Miyake, Y.; Nakamura, M.; Nabetani, A.; Shimamura, S.; Tamura, M.; Yonehara, S.; Saito, M.; Ishikawa, F. RPA-like mammalian Ctc1-Stn1-Ten1 complex binds to single-stranded DNA and protects telomeres independently of the Pot1 pathway. Mol. Cell 2009, 36, 193-206. [CrossRef]

10. Soudet, J.; Jolivet, P.; Teixeira, M.T. Elucidation of the DNA End-Replication Problem in Saccharomyces cerevisiae. Mol. Cell 2014, 53, 954-964. [CrossRef]

11. Wellinger, R.J. In the End. What's the Problem? Mol. Cell 2014, 53, 855-856. [CrossRef] [PubMed]

12. Watson, J.D. Origins of concatemeric T7DNA. Nat. New Biol. 1972, 239, 197-201. [CrossRef] [PubMed]

13. Wellinger, R.J.; Zakian, V.A. Everything You Ever Wanted to Know About Saccharomyces cerevisiae Telomeres: Beginning to End. Genetics 2012, 191, 1073-1105. [CrossRef] [PubMed] 
14. Kupiec, M. Biology of telomeres: Lessons from budding yeast. FEMS Microbiol. Rev. 2014, 38, $144-171$. [CrossRef] [PubMed]

15. Malyavko, A.N.; Parfenova, Y.Y.; Zvereva, M.I.; Dontsova, O.A. Telomere length regulation in budding yeasts. FEBS Lett. 2014, 588, 2530-2536. [CrossRef] [PubMed]

16. Maciejowski, J.; de Lange, T. Telomeres in cancer: Tumour suppression and genome instability. Nat. Rev. Mol. Cell Biol. 2017, 18, 175-186. [CrossRef] [PubMed]

17. Palm, W.; Lange, T.D. How Shelterin Protects Mammalian Telomeres. Annu. Rev. Genet. 2008, 42, 301-334. [CrossRef]

18. Wang, Y.; Sharpless, N.; Chang, S. p16(INK4a) protects against dysfunctional telomere-induced ATR-dependent DNA damage responses. J. Clin. Investig. 2013, 123, 4489-4501. [CrossRef]

19. Kibe, T.; Zimmermann, M.; de Lange, T. TPP1 Blocks an ATR-Mediated Resection Mechanism at Telomeres. Mol. Cell 2016, 61, 236-246. [CrossRef]

20. Mortimer, R.K.; Johnston, J.R. Life Span of Individual Yeast Cells. Nature 1959, 183, 1751-1752. [CrossRef]

21. Kaeberlein, M.; Powers, R.W., 3rd; Steffen, K.K.; Westman, E.A.; Hu, D.; Dang, N.; Kerr, E.O.; Kirkland, K.T.; Fields, S.; Kennedy, B.K. Regulation of yeast replicative life span by TOR and Sch9 in response to nutrients. Science 2005, 310, 1193-1196. [CrossRef] [PubMed]

22. Sarnoski, E.A.; Liu, P.; Acar, M. A High-Throughput Screen for Yeast Replicative Lifespan Identifies Lifespan-Extending Compounds. Cell Rep. 2017, 21, 2639-2646. [CrossRef] [PubMed]

23. McCormick Mark, A.; Delaney Joe, R.; Tsuchiya, M.; Tsuchiyama, S.; Shemorry, A.; Sim, S.; Chou Annie, C.-Z.; Ahmed, U.; Carr, D.; Murakami Christopher, J.; et al. A Comprehensive Analysis of Replicative Lifespan in 4,698 Single-Gene Deletion Strains Uncovers Conserved Mechanisms of Aging. Cell Metab. 2015, 22, 895-906. [CrossRef] [PubMed]

24. Chen, K.L.; Crane, M.M.; Kaeberlein, M. Microfluidic technologies for yeast replicative lifespan studies. Mech. Ageing Dev. 2017, 161, 262-269. [CrossRef]

25. He, C.; Zhou, C.; Kennedy, B.K. The yeast replicative aging model. Biochim. Biophys. Acta 2018, 2690-2696. [CrossRef] [PubMed]

26. Longo, V.D.; Shadel, G.S.; Kaeberlein, M.; Kennedy, B. Replicative and Chronological Aging in Saccharomyces cerevisiae. Cell Metab. 2012, 16, 18-31. [CrossRef] [PubMed]

27. Shay, J.W.; Wright, W.E. Senescence and immortalization: Role of telomeres and telomerase. Carcinogenesis 2005, 26, 867-874. [CrossRef]

28. Lundblad, V.; Blackburn, E.H. An alternative pathway for yeast telomere maintenance rescues est1senescence. Cell 1993, 73, 347-360. [CrossRef]

29. Teng, S.-C.; Zakian, V.A. Telomere-Telomere Recombination Is an Efficient Bypass Pathway for Telomere Maintenance in Saccharomyces cerevisiae. Mol. Cell. Biol. 1999, 19, 8083-8093. [CrossRef]

30. Hayflick, L.; Moorhead, P. The serial cultivation of human diploid cell strains. Exp. Cell Res. 1961, $25,585-621$. [CrossRef]

31. Hayflick, L. The Limited in Vitro Lifetime of Human Diploid Cell Strains. Exp. Cell Res. 1965, 37, 614-636. [CrossRef]

32. Watts, G. Leonard Hayflick and the limits of ageing. Lancet 2011, 377, 2075. [CrossRef]

33. Fabrizio, P.; Longo, V.D. The chronological life span of Saccharomyces cerevisiae. Aging Cell 2003, 2, 73-81. [CrossRef]

34. Fabrizio, P.; Longo, V. The Chronological Life Span of Saccharomyces cerevisiae in Biological Aging; Humana Press: New York, NY, USA, 2007; pp. 89-95.

35. Powers, R.W., 3rd; Kaeberlein, M.; Caldwell, S.D.; Kennedy, B.K.; Fields, S. Extension of chronological life span in yeast by decreased TOR pathway signaling. Genes Dev. 2006, 20, 174-184. [CrossRef] [PubMed]

36. Huang, X.; Liu, J.; Dickson, R.C. Down-Regulating Sphingolipid Synthesis Increases Yeast Lifespan. PLoS Genet. 2012, 8, e1002493. [CrossRef] [PubMed]

37. Liu, J.; Huang, X.; Withers, B.R.; Blalock, E.; Liu, K.; Dickson, R.C. Reducing Sphingolipid Synthesis Orchestrates Global Changes to Extend Yeast Lifespan. Aging Cell 2013, 12, 833-841. [CrossRef] [PubMed]

38. Burtner, C.R.; Murakami, C.J.; Kennedy, B.K.; Kaeberlein, M. A molecular mechanism of chronological aging in yeast. Cell Cycle 2009, 8, 1256-1270. [CrossRef] [PubMed]

39. Matecic, M.; Smith, D.L., Jr.; Pan, X.; Maqani, N.; Bekiranov, S.; Boeke, J.D.; Smith, J.S. A Microarray-Based Genetic Screen for Yeast Chronological Aging Factors. PLoS Genet. 2010, 6, e1000921. [CrossRef] 
40. Burtner, C.R.; Murakami, C.J.; Olsen, B.; Kennedy, B.K.; Kaeberlein, M. A genomic analysis of chronological longevity factors in budding yeast. Cell Cycle 2011, 10, 1385-1396. [CrossRef]

41. Huang, X.; Liu, J.; Withers, B.R.; Samide, A.J.; Leggas, M.; Dickson, R.C. Reducing signs of aging and increasing lifespan by drug synergy. Aging Cell 2013, 12, 652-660. [CrossRef]

42. Liu, J.; He, M.-H.; Peng, J.; Duan, Y.-M.; Lu, Y.-S.; Wu, Z.; Gong, T.; Li, H.-T.; Zhou, J.-Q. Tethering telomerase to telomeres increases genome instability and promotes chronological aging in yeast. Aging 2016, 8, 2827-2840. [CrossRef] [PubMed]

43. Sarto-Jackson, I.; Tomaska, L. How to bake a brain: Yeast as a model neuron. Curr. Genet. 2016, 62, 347-370. [CrossRef] [PubMed]

44. Ruetenik, A.; Barrientos, A. Exploiting Post-mitotic Yeast Cultures to Model Neurodegeneration. Front. Mol. Neurosci. 2018, 11, 400. [CrossRef] [PubMed]

45. Chen, Q.; Ding, Q.; Keller, J.N. The stationary phase model of aging in yeast for the study of oxidative stress and age-related neurodegeneration. Biogerontology 2005, 6, 1-13. [CrossRef] [PubMed]

46. Hofer, S.; Kainz, K.; Zimmermann, A.; Bauer, M.A.; Pendl, T.; Poglitsch, M.; Madeo, F.; Carmona-Gutierrez, D. Studying Huntington's Disease in Yeast: From Mechanisms to Pharmacological Approaches. Front. Mol. Neurosci. 2018, 11, 318. [CrossRef] [PubMed]

47. Shrestha, A.; Megeney, L.A. Yeast proteinopathy models: A robust tool for deciphering the basis of neurodegeneration. Microb. Cell 2015, 2, 458-465. [CrossRef] [PubMed]

48. Khurana, V.; Lindquist, S. Modelling neurodegeneration in Saccharomyces cerevisiae: Why cook with baker's yeast? Nat. Rev. Neurosci. 2010, 11, 436. [CrossRef]

49. Tenreiro, S.; Outeiro, T.F. Simple is good: Yeast models of neurodegeneration. FEMS Yeast Res. 2010, 10, 970-979. [CrossRef]

50. Bodnar, A.G.; Ouellette, M.; Frolkis, M.; Holt, S.E.; Chiu, C.-P.; Morin, G.B.; Harley, C.B.; Shay, J.W.; Lichtsteiner, S.; Wright, W.E. Extension of Life-Span by Introduction of Telomerase into Normal Human Cells. Science 1998, 279, 349-352. [CrossRef]

51. De Lange, T. Telomeres and Senescence: Ending the Debate. Science 1998, 279, 334-335. [CrossRef]

52. Chen, X.-F.; Meng, F.-L.; Zhou, J.-Q. Telomere Recombination Accelerates Cellular Aging in Saccharomyces cerevisiae. PLoS Genet. 2009, 5, e1000535. [CrossRef] [PubMed]

53. Ramunas, J.; Yakubov, E.; Brady, J.; Corbel, S.; Holbrook, C.; Brandt, M.; Stein, J.; Santiago, J.; Cooke, J.; Blau, H. Transient delivery of modified mRNA encoding TERT rapidly extends telomeres in human cells. FASEB J. 2015, 29, 1930-1939. [CrossRef] [PubMed]

54. Rubio, M.A.; Kim, S.-H.; Campisi, J. Reversible Manipulation of Telomerase Expression and Telomere Length: Implications for the ionizing radiation response and replicative senescence of human cells. J. Biol. Chem. 2002, 277, 28609-28617. [CrossRef] [PubMed]

55. Austriaco, N.R.; Guarente, L.P. Changes of telomere length cause reciprocal changes in the lifespan of mother cells in Saccharomyces cerevisiae. Proc. Natl. Acad. Sci. USA 1997, 94, 9768-9772. [CrossRef] [PubMed]

56. Peng, J.; He, M.-H.; Duan, Y.-M.; Liu, Y.-T.; Zhou, J.-Q. Inhibition of Telomere Recombination by Inactivation of KEOPS Subunit Cgi121 Promotes Cell Longevity. PLoS Genet. 2015, 11, e1005071. [CrossRef] [PubMed]

57. Harari, Y.; Kupiec, M. Do long telomeres affect cellular fitness? Curr. Genet. 2018, 64, 173-176. [CrossRef] [PubMed]

58. Tomas-Loba, A.; Flores, I.; Fernandez-Marcos, P.J.; Cayuela, M.L.; Maraver, A.; Tejera, A.; Borras, C.; Matheu, A.; Klatt, P.; Flores, J.M.; et al. Telomerase reverse transcriptase delays aging in cancer-resistant mice. Cell 2008, 135, 609-622. [CrossRef] [PubMed]

59. Bernardes de Jesus, B.; Schneeberger, K.; Vera, E.; Tejera, A.; Harley, C.; Blasco, M. The telomerase activator TA-65 elongates short telomeres and increases health span of adult/old mice without increasing cancer incidence. Aging Cell 2011, 10, 604-621. [CrossRef]

60. Bernardes de Jesus, B.; Vera, E.; Schneeberger, K.; Tejera, A.M.; Ayuso, E.; Bosch, F.; Blasco, M.A. Telomerase gene therapy in adult and old mice delays aging and increases longevity without increasing cancer. $E M B O$ Mol. Med. 2012, 4, 691-704. [CrossRef]

61. Codd, V.; Nelson, C.P.; Albrecht, E.; Mangino, M.; Deelen, J.; Buxton, J.; Hottenga, J.J.; Fischer, K.; Esko, T.; Surakka, I.; et al. Identification of seven loci affecting mean telomere length and their association with disease. Nat. Genet. 2013, 45, 422-427. [CrossRef] 
62. Joeng, K.S.; Song, E.J.; Lee, K.-J.; Lee, J. Long lifespan in worms with long telomeric DNA. Nat. Genet. 2004, 36, 607. [CrossRef] [PubMed]

63. Izikki, M.; Hoang, E.; Draskovic, I.; Mercier, O.; Lecerf, F.; Lamrani, L.; Liu, W.-Y.; Guignabert, C.; Fadel, E.; Dorfmuller, P.; et al. Telomere Maintenance Is a Critical Determinant in the Physiopathology of Pulmonary Hypertension. J. Am. Coll. Cardiol. 2015, 66, 1942-1943. [CrossRef] [PubMed]

64. Cao, Y.; Li, H.; Mu, F.-T.; Ebisui, O.; Funder, J.W.; Liu, J.P. Telomerase activation causes vascular smooth muscle cell proliferation in genetic hypertension. FASEB J 2002, 16, 96-98. [CrossRef] [PubMed]

65. Zhang, C.; Doherty, J.A.; Burgess, S.; Hung, R.J.; Lindström, S.; Kraft, P.; Gong, J.; Amos, C.I.; Sellers, T.A.; Monteiro, A.N.A.; et al. Genetic determinants of telomere length and risk of common cancers: A Mendelian randomization study. Hum. Mol. Genet. 2015, 24, 5356-5366. [CrossRef] [PubMed]

66. Shaheen, F.; Grammatopoulos, D.K.; Muller, J.; Zammit, V.A.; Lehnert, H. Extra-nuclear telomerase reverse transcriptase (TERT) regulates glucose transport in skeletal muscle cells. Biochim. Biophys. Acta 2014, 1762-1769. [CrossRef] [PubMed]

67. Missios, P.; Zhou, Y.; Guachalla, L.M.; von Figura, G.; Wegner, A.; Chakkarappan, S.R.; Binz, T.; Gompf, A.; Hartleben, G.; Burkhalter, M.D.; et al. Glucose substitution prolongs maintenance of energy homeostasis and lifespan of telomere dysfunctional mice. Nat. Commun. 2014, 5, 4924. [CrossRef] [PubMed]

68. Ma, Z.; Wang, H.; Cai, Y.; Wang, H.; Niu, K.; Wu, X.; Ma, H.; Yang, Y.; Tong, W.; Liu, F.; et al. Epigenetic drift of H3K27me3 in aging links glycolysis to healthy longevity in Drosophila. eLife 2018, 7, e35368. [CrossRef] [PubMed]

69. Chen, R.; Zhang, K.; Chen, H.; Zhao, X.; Wang, J.; Li, L.; Cong, Y.; Ju, Z.; Xu, D.; Williams, B.R.; et al. Telomerase deficiency causes alveolar stem cell senescence-associated low-grade inflammation in lungs. J. Biol. Chem. 2015, 290, 30813-30829. [CrossRef] [PubMed]

70. Cassar, L.; Nicholls, C.; Pinto, A.R.; Chen, R.; Wang, L.; Li, H.; Liu, J.P. TGF-beta receptor mediated telomerase inhibition. telomere shortening and breast cancer cell senescence. Protein Cell 2017, 8, 39-54. [CrossRef] [PubMed]

71. Li, H.; Xu, D.; Li, J.; Berndt, M.C.; Liu, J.P. Transforming Growth Factor beta Suppresses Human Telomerase Reverse Transcriptase (hTERT) by Smad3 Interactions with c-Myc and the hTERT Gene. J. Biol. Chem. 2006, 281, 25588-25600. [CrossRef] [PubMed]

72. Yu, Q.; Katlinskaya, Y.V.; Carbone, C.J.; Zhao, B.; Katlinski, K.V.; Zheng, H.; Guha, M.; Li, N.; Chen, Q.; Yang, T.; et al. DNA-damage-induced type I interferon promotes senescence and inhibits stem cell function. Cell Rep. 2015, 11, 785-797. [CrossRef] [PubMed]

73. Vera, E.; Bernardes de Jesus, B.; Foronda, M.; Flores, J.M.; Blasco, M.A. The rate of increase of short telomeres predicts longevity in mammals. Cell Rep. 2012, 2, 732-737. [CrossRef] [PubMed]

74. Tacutu, R.; Craig, T.; Budovsky, A.; Wuttke, D.; Lehmann, G.; Taranukha, D.; Costa, J.; Fraifeld, V.E.; de Magalhaes, J.P. Human Ageing Genomic Resources: Integrated databases and tools for the biology and genetics of ageing. Nucleic Acids Res. 2013, 41, D1027-D1033. [CrossRef] [PubMed]

75. Cawthon, R.M.; Smith, K.R.; O’Brien, E.; Sivatchenko, A.; Kerber, R.A. Association between telomere length in blood and mortality in people aged 60 years or older. Lancet 2003, 361,393-395. [CrossRef]

76. Haussmann, M.F.; Winkler, D.W.; Huntington, C.E.; Nisbet, I.C.; Vleck, C.M. Telomerase activity is maintained throughout the lifespan of long-lived birds. Exp. Gerontol. 2007, 42, 610-618. [CrossRef] [PubMed]

77. Gorbunova, V.; Seluanov, A. Coevolution of telomerase activity and body mass in mammals: From mice to beavers. Mech. Ageing Dev. 2009, 130, 3-9. [CrossRef] [PubMed]

78. Seluanov, A.; Chen, Z.; Hine, C.; Sasahara, T.H.; Ribeiro, A.A.; Catania, K.C.; Presgraves, D.C.; Gorbunova, V. Telomerase activity coevolves with body mass not lifespan. Aging Cell 2007, 6, 45-52. [CrossRef]

79. Xie, Z.; Jay, K.A.; Smith, D.L.; Zhang, Y.; Liu, Z.; Zheng, J.; Tian, R.; Li, H.; Blackburn, E.H. Early Telomerase Inactivation Accelerates Aging Independently of Telomere Length. Cell 2015, 160, 928-939. [CrossRef]

80. Gallardo, F.; Laterreur, N.; Cusanelli, E.; Ouenzar, F.; Querido, E.; Wellinger, R.J.; Chartrand, P. Live Cell Imaging of Telomerase RNA Dynamics Reveals Cell Cycle-Dependent Clustering of Telomerase at Elongating Telomeres. Mol. Cell 2011, 44, 819-827. [CrossRef]

81. Luo, K.; Vega-Palas, M.A.; Grunstein, M. Rap1-Sir4 binding independent of other Sir. yKu, or histone interactions initiates the assembly of telomeric heterochromatin in yeast. Genes Dev. 2002, 16, 1528-1539. [CrossRef] 
82. Aparicio, O.M.; Billington, B.L.; Gottschling, D.E. Modifiers of position effect are shared between telomeric and silent mating-type loci in S. cerevisiae. Cell 1991, 66, 1279-1287. [CrossRef]

83. Kueng, S.; Oppikofer, M.; Gasser, S.M. SIR Proteins and the Assembly of Silent Chromatin in Budding Yeast. Annu. Rev. Genet. 2013, 47, 275-306. [CrossRef] [PubMed]

84. Pfingsten, J.; Goodrich, K.; Taabazuing, C.; Ouenzar, F.; Chartrand, P.; Cech, T. Mutually Exclusive Binding of Telomerase RNA and DNA by Ku Alters Telomerase Recruitment Model. Cell 2012, 148, 922-932. [CrossRef] [PubMed]

85. Hass, E.P.; Zappulla, D.C. The Ku subunit of telomerase binds Sir4 to recruit telomerase to lengthen telomeres in S. cerevisiae. eLife 2015, 4, e07750. [CrossRef] [PubMed]

86. Chen, H.; Xue, J.; Churikov, D.; Hass, E.P.; Shi, S.; Lemon, L.D.; Luciano, P.; Bertuch, A.A.; Zappulla, D.C.; Géli, V.; et al. Structural Insights into Yeast Telomerase Recruitment to Telomeres. Cell 2018, 172, 331-343.e13. [CrossRef] [PubMed]

87. Evans, S.K.; Lundblad, V. Est1 and Cdc13 as Comediators of Telomerase Access. Science 1999, 286, 117-120. [CrossRef] [PubMed]

88. Loewith, R.; Hall, M.N. Target of rapamycin (TOR) in nutrient signaling and growth control. Genetics 2011, 189, 1177-1201. [CrossRef]

(C) 2019 by the authors. Licensee MDPI, Basel, Switzerland. This article is an open access article distributed under the terms and conditions of the Creative Commons Attribution (CC BY) license (http://creativecommons.org/licenses/by/4.0/). 